\title{
Opinion on the Post-modernism
}

\author{
Qiong Liu \\ Medical School \\ Xi'an Peihua University \\ Xi'an, China
}

Feng Ma

School of Civil Engineering

Beijing Jiaotong University

Beijing, China

\author{
Libing Liu* \\ Medical School \\ Xi'an Peihua University \\ Xi'an, China \\ *Corresponding Author
}

\author{
Xiaying Lv \\ School of Marxism \\ Zhejiang University \\ Hangzhou, China
}

\begin{abstract}
Post-modernism is one of the most important social trends in contemporary Western society and is also a major trend of thought in the academic and ideological world of our country. Post-modernism is thinking and answering on the negative effect of industrial civilization and originated from it. It is a correction and rebellion to western traditional philosophy and western modern society. Our country is in the process of modernization. Correctly understanding post-modernism and rationally drawing its beneficial components has far-reaching implications and significance for China's modernization cause.
\end{abstract}

Keywords—post-modernism; content; evaluation; Chinese modernization

\section{INTRODUCTION}

In today's society, social ideological trends are diversified. How to ensure Marxism's dominance in the complex social trends of thought requires the identification and analysis of various ideological trends, the depreciation of their essence, and the wide spread of Marxism. Post-modernism is one of the mainstream social trends of modern western society. This article mainly analyzes the meaning and content of postmodernism, and then evaluates its impact on social thoughts in China. Through analysis and comparison, we establish correct understanding and avoid blindly follow and promote the sound development of China's social culture.

\section{THE BACKGROUND OF POST-MODERNISM}

Post-modernism is a social and cultural trend of thought produced in the West in the 1960s. It involves art, literature, philosophy, science, and other fields, and it has quickly become a hot topic and mainstream in Western academic circles. In the 1980s, Chinese cultural and ideological circles began to introduce post-modernism trends. After entering the 1990 s, post-modernism has gradually become a major trend of thought in the Chinese academia and ideology. For a time, various post-modernism trends are mixed, and post-modernism is common all over the world. Even modern things are often flaunted with post-modernism plaques, and post-modernism has become synonymous with new trends.

\section{THE MEANING OF POST-MODERNISM}

The term "post-modernism" emerged in the middle of the 20th century. The intention was to abandon the architectural style of universalism and critical modernism. Later, it was used to refer to literature, art, philosophy, sociology, political science, and even the field of natural science also has a similar trend of social thought. Strictly speaking, post-modernism does not have a clear definition. It is not a unified school or theory. It even contains some contradictory ideas. We can understand the concrete meaning of post-modernism through modernism. Modernism refers to the performance of social practice in the modern and contemporary bourgeoisie in the field of culture and consciousness. It is a social practice of modern bourgeoisie that is manifested in a cultural form. The core of modernism is humanitarianism and rationalism. It advocates humanism and opposes Shinto. It advocates rationality and advocates using reason to defeat everything and measure everything. ${ }^{1}$ In the process of Western industrialization and modernization, modernism has played an important role. However, in this process, modernism gradually went to the extreme: Reason becomes instrumental rationality, and people are slaves to instrumental rationality. It is precisely because of the reaction of modernism that post-modernism emerged. post-modernism refers first to temporal precedence, that is, post-modernism is the thing that occurs after modernism; at the same time, there is still an ideological and logical relationship between post-modernism and modernism. , that is, post-modern refers to non-modern, it is a criticism of modernity, is a complete break and reflective criticism with the modern. Therefore, post-modernism is a general term for a new social trend of thought originating from modernism and criticizing and correcting modernism.

Duan Zhongqiao Contemporary Social Trends in Contemporary China: Beijing: Renmin University of China Press, 2010, p. 86 


\section{THE MAIN CONTENT OF POST-MODERNISM}

\section{A. Oppose Rationality and Eliminate the Subjectivity}

Rationality is the most reliable tool and the most powerful weapon in Western society's enlightenment. It destroys the spiritual pillar of feudal society-religious theology, removes obstacles to the development of modern capitalism, liberates people's thoughts, and brings people valuable spiritual wealth. However, the over-expansion of reason, especially the rationality of science and technology, has brought many negative effects and even disasters to the modern society. The main manifestation is that the natural environment has been severely damaged, and the living environment of human beings has deteriorated drastically. Post-modernism believes that reviewing the progress of Western civilization has proven that the development of scientific rationality does not bring unexpected freedom and happiness to people. Instead, it eliminates enslavement and repression and sets new enslavement and suppression. It also formed a new "authority", "essence" and "center." These ideas influence people's thinking and make people lose their autonomy while also enduring internal and external pressures and anxiety. Therefore, postmodernism put forward: opposing reason and eliminating subjectivity. Derrida, a famous French philosopher, said, "Beyond the text, nothing else," everything is a game, and "the rules of the game have been replaced by the game itself." The American philosopher Rorty pointed out that "rationality" is not what people usually think of as "orderliness" or "having a pre-determined standard of success, but rather a kind of "sober" and "reasonable", which is a kind of "moral virtue". 2Nihilistic Attitudes of "Non-foundation", "Fragmentation", and "People Are Dead" and "How They Are All OK" will inevitably lead to the conclusion that "the loss of reason" "the demise of the subject".

\section{B. Advocating Uncertainty and Promoting Diversity and Heterogeneity}

The period of modern society is the period when science dominates. What science seeks is certainty and regularity. However, with the continuous improvement of human cognition capabilities, people's understanding of the world is increasingly showing uncertainties. All the original certainty and regularity began to lose its due recognition. Thus, uncertainty is another important aspect of post-modernism. As Derrida said, "meaning is uncertain." He also specializes in the creation of a word - "differ-delay" (ie, "differentiate" and "delay") to break down the structural certainty. The French post-modernist Leoota once said: "Let us start war on the unity as a whole and let us be witnesses of unspeakable things. Let us make no compromises in the development of all kinds of differences and let us work hard to make different honor." 3 Post-modernism is to express a kind of "fuzzy" and "accidental" and "non-settable" mental state, that is, the world is not an interconnected whole, it does not have the sameness between the same things, and the connection between the

Duan Zhongqiao Contemporary social thoughts abroad: Beijing: Renmin University of China Press, 2010, p. 111

[France] Liotta Postmodernism - Report on Knowledge Changsha: Hunan Fine Arts Publishing House 1996 Edition Page 211 things is accidental and relative, as reading a book, different people can read different meanings. One thousand spectators have a thousand Hamlets in their hearts. Post-modernism pursues diversity and innovation.

\section{Against Fundamentalism and Essential Reductionism}

Post-modernism points out that the traditional philosophy of ancient and modern China and foreign countries have always attributed all things in the world to a "foundation" and essence, and that all things are originated here and restored to it. Traditional philosophy believes that the understanding of things is to pursue the "foundation" and essence of things, and to understand the nature of things through superficial phenomena. Post-modernism refers to this view of traditional philosophy as "fundamentalism" or "essential reductionism," and points out that "foundation" and "ultimate essence" are metaphysical "attendance", which is one expression form of $\operatorname{logos} 4$. Post-modernism believes that there is no ultimate source in the world and that people have never been able to reach an absolute basis and demand the destruction and deconstruction of such "fundamentalism" and "essentialism". They also pointed out that traditional philosophy believes that language can reflect and express objects, the concept of people's understanding the nature and laws of the world through the language expressions of the people who know it is a "logocentrism" and "Language centralism" that must be broken. Derrida deconstructs logocentrism through Saussure's linguistic structuralism. According to Saussure's principles of arbitrariness and difference, "the connection between the signifier and the signified is arbitrary and conventional, and the meaning of the sign depends on the difference between signs", that is to say depends on other signs. Through this deconstruction, on the one hand, Derrida breaks the existing closed system of traditional philosophy, and on the other hand exposes various factors of the disintegrated system to the outside world, and taps into its hidden information to make the original factor. With the free combination of external factors, so that things are constantly pouring out, things outside continue to substitute for the original things inside, thus forming a meaningless network of meaning. As a result, the attendance is constantly being negated, and the center is no longer there. That is, there is no such thing as "foundation" and "essence."

\section{Emphasizing the Pragmatism of the Truth and Promoting the End of the Truth}

The post-modernists believe that there is no inherent "foundation" and "essence" in things that are waiting for people to objectively and truthfully reflect and grasp, the nature and meaning of things only exist in people's reading and interpretation of things. Post-modernism replaced the coincidence theory of truth with a pragmatic view of truth combined with subjectivist truth. Post-modernism is an era of deep-cutting and history annihilation. The undertakings that have been created for generations have been dismantled by the

In Greek, logos have the meaning of thinking and speaking, and they derive the meaning of "thoughts, laws, ideas, and languages". Western philosophers generally believe that logos refer to fundamental things that exist within things. 
current philosophers. The intellectuals who bear the conscience have died. The truth has lost the standard of judgment and has lost its meaning. The grand narrative system of absolute truth collapsed and even the name of human liberation was abandoned.

Since the "foundation" "essence" has been dissolved, the knowledge gained from reflection theory is naturally denied. Post-modernism recognizes that knowledge is a commodity, and the highest purpose of knowledge is to pursue profit and to produce for sale. Knowledge is no longer the pursuit of truth, and the relationship between creators and users of knowledge is also tending towards a pattern of supply and demand similar between commodity producers and consumers.

\section{E. Praise the Language Game Theory}

Post-modernist thinkers believe that in the future industrial society, the philosophical linguistic concept should shift from grammar-logic to practice-pragmatics, and the meaning of language lies in its usage. The reason that the language of knowledge expresses some meaning is not because it expresses something certain, but because of the actual effect of language in the specific use process. Post-modernism does not admit the universal rationality of the rules. It holds that rules can only be formulated by the people involved in language games through mutual agreement. Such rules are naturally formed in language games and are a kind of language habits. It will only be effective for those who use the language. The use of language does not obey certain rules, so people can think freely in language games and maximize their imagination and creativity. At the same time, due to differences and disagreements in the individual's free imagination, they need to be tolerant and respectful each other, and thus cannot allow metaphysical prejudice to exist. At the extremes of post-modernism, the game itself has completely replaced the rules of the game.

\section{A BRIEF EVALUATION OF POST-MODERNISM}

First of all, post-modernism, with a fearless critical spirit, reveals and criticizes various shortcomings in the process of western capitalist modernization. It helps people to recognize the true features of capitalism and undoubtedly has positive revelation and warning for countries that are undergoing modernization and modernization. At the same time, the spirit of innovation, anti-tradition, and anti-authority shown by postmodernism, as well as its emphasis on diversity and diversity, has broken the traditional way of thinking that binds humans and promotes the development of human thinking, which worth to learn.

Second, post-modernism is a "correction" of traditional philosophy and the reality of capitalism, but there are also certain phenomena of "overkill." It blindly criticizes rationality, eliminates subjectivity, denies the existence of objective truth, overemphasizes uncertainty, and ultimately retreats to skepticism and nihilism. It regards the means of criticizing and deconstructing this dismantling traditional philosophy as the goal itself, and ultimately it can only be lost in criticism and deconstruction, becoming a metaphysics that against metaphysics.
Third, as a social trend of thought, post-modernism involves all aspects of social life. It criticizes the alienation of human civilization by industrial civilization, emphasizes diversity, heterogeneity, and counter-authority, There are similarities with Marxism's ultimate goal ultimately achieving the full emancipation of human freedom .but the lack of a unified scientific theoretical basis for the post-modernism trend of thought is the theoretical generalization of similar social phenomena in the outside world. Therefore, the lack of support for the theoretical foundation will inevitably die out as the social phenomenon disappears.

\section{CONCLUSION}

Post-modernism is one of the most important social trends in contemporary Western society, and it is also a major trend of thought in the academic and ideological world of China today. We must clearly understand that China is still a country with pre-modernization, modernization and postmodernization coexisting. The full realization of modernization is still our country's current priority. In our country, science and technology and reason have not developed to the extent that they face the opposite. At present, the Chinese society still needs science and technology and reason. Therefore, for the post-modernist social ideological trend, we must use its beneficial elements for reference, study its criticism of the negative impact of western modernization, avoid our country from repeating the mistakes in the process of modernization, absorb its innovative spirit, resist the spirit of authority, and encourage innovation thinking, but also take into account the differences and rejuvenate society. In addition, we must consciously resist the negative influence of postmodernism, strengthen Marxist education, and promote socialist core values. In particular, young people who are ideologically active and vulnerable to post-modernism are required to carry out key education to make them fully understand and understand post-modernism and avoid blind obedience. Only in this way can we avoid falling into the embarrassing situation of not having completely escaped from the traditional society and entering the modern society, but also into the post-modern society.

\section{REFERENCES}

[1] Hong Xiaonan Contemporary Western Social Trend of Thought and Its Influence [M] Beijing: People's Publishing House 2009 Edition. 洪晓楠 当代西方社会思潮及其影响 [M] 北京: 人民出版社 2009 年版

[2] Wang Min Contemporary Western Thought Review [M] Hangzhou: Zhejiang University Press 2005 Edition. 王珉 当代西方思潮评介 [M] 杭州: 浙大出版社 2005 年版

[3] Gao Xuanyang Post-modernism[M] Beijing: Renmin University of China Press 2005 Edition. 高宣扬 后现代论 [M] 北京: 中国人民 大学出版社 2005 年版

[4] Duan Zhongqiao Contemporary social thoughts in foreign countries[M] Beijing: Renmin University of China Press 2010 Edition. 段忠桥 当代 国外社会思潮 [M] 北京: 中国人民大学出版社 2010 年版

[5] Shi Suyi \&Mu Yangyuan Analysis of the Influence of Western Postmodernism on China[J] Journal of Social Science of Shanxi Higher School, No.11(2010). 石苏谊 穆阳远 西方后现代主义对中国的影响 分析 $[\mathrm{J}]$ 山西高等学校社会科学学报 2010 年第 1 期 
[6] Jiao Mingjia A Further Discussion on Post-modernism Theory --- From Marxist Perspective[J] Frontier No.11 (2010). 焦明甲 再论后现代主义 理论一一从马克思主义视角看 [J] 前沿 2010 年第 11 期

[7] $\mathrm{Li}$ Xinling The Inspiration of Post-modernism to China's Modernization[J] Journal of Changsha University of Science and Technology(Social Sciences) No.2(2010). 李新灵 后现代主义对中国 现代化的启示 $[\mathrm{J}]$ 长沙理工大学学报（社科版） 2010 年第 2 期 